\title{
LOJALŲ KLIENTĄ FORMUOJANTI APLINKA FITNESO ORGANIZACIJOJE
}

\author{
Diana Komskienė, Ernesta Urbonavičiūtè \\ Lietuvos sporto universitetas, Kaunas, Lietuva
}

\begin{abstract}
ANOTACIJA
Mokslinès studijos patvirtina, kad kelias ị organizacijos pelningumą yra lojalaus kliento formavimas, kai tuo tarpu fitneso sektoriaus finansinis stabilumas yra tik fragmentiškas. Fitneso organizaciju lankytojai yra skirtingos asmenybès su panašiais poreikiais, tačiau jie skirtingi dèl psichologinių, socialinių ir demografinių veiksnių. Fitneso organizacijų paslaugų naudos kūrimas yra ilgalaikis procesas ir nesuteikia greitų rezultatų, dèl to gali mažinti žmogaus norą sportuoti arba visai atsisakoma šios veiklos. Taigi fitneso organizacijoms yra gyvybiškai svarbu formuoti lojalų klientą per aplinką, pasitelkiant asmenines žmogaus savybes, užtikrinant pasitenkinimą, kuris tiesiogiai susijęs su lojalumu.
\end{abstract}

Raktažodžiai: lojalus klientas, pasitenkinimas, paslauga, fitneso organizacija.

\section{IVADAS}

Lojalumas yra gyvybiškai svarbus kiekvienai sporto organizacijai. Visgi manoma, kad suformuoti lojalų vartotoją yra sunku, nes lojalumas yra trapus ir nepastovus reiškinys. Šiandieninis fitneso sektoriaus pelningumas yra stipriai fragmentiškas, o lojalumas, kaip teigiama, dažnai gali užtikrinti pastovias pajamas, sumažèjusias marketingo išlaidas, mažesni jautrumą kainos svyravimams. Todèl svarbu nustatyti, kokie veiksniai formuoja lojalią aplinką fitneso organizacijoje. Kokie veiksniai labiausiai veikia lojalaus kliento formavimą ir kaip organizacija gali išsiugdyti ir išlaikyti klientą, kuris atneštų organizacijai naudos ir skatintų ją tobulèti, augti. Taigi vartotojų lojalumo formavimosi veiksnius tyrinèja daug autorių, iš kurių galima paminèti šiuos: G. Bodet (2012), T. Durukan ir I. Bozaci (2011), R. Hawkins ir P. Vel (2013),) F. F. Reichheld (2003, 2006), R. Tsioutsou (2013), L. Pilelienè (2008), A. Bakanauskas ir L. Pilelienè (2008, 2009), R. Zikienė (2010), J. Bivainis ir kt. (2011). Šis tyrimas yra teorinis - aiškintasi, kaip formuojamas lojalus klientas, atsižvelgiant i sąsajas su įtaką darančia aplinka fitneso organizacijoje. Naudoti tyrimo metodai: mokslinès literatūros analizè ir sisteminimas.

Tikslas - nustatyti lojalų klientą formuojančią aplinką fitneso organizacijoje.

Objektas: lojalų klientą formuojanti aplinka.

\section{Uždaviniai:}

1. Apibūdinti lojalumo sampratą ir raišką.

2. Atskleisti lojalų klientą formuojančių veiksnių ịtaką fitneso organizacijos aplinkai.

\section{Lojalumo samprata ir raiška}

Lojalumas mokslinèse studijose apibrěžiamas kaip trapus reiškinys, pakankamai nepastovus ir siejasi su tam tikromis asociacijomis - tokiomis kaip ištikimybė, atsidavimas (Donskis, 2005; Tsioutsou, 2013), noras palaikyti ryši (Pilelienè, 2008) su konkrečiu tiekèju, produktu ar prekès ženklu (Hawkins,Vel, 2013). Tam tikra žmogaus elgsena susijusi su ilgalaikiu naudojimu, pripratimu (Sin et al., 2006; Vanagienè, Ramanauskienè, 2007; Papšienè, Vilkaite, 2009), kuris 
igyjamas per emocinę sąveiką: pagarbą, žavesị, rūpestị (Vanagienė, Ramanauskienė, 2007), pereinantis kelias stadijas (Bakanauskas, Pilelienè, 2008) ir susijęs su pakartotiniais pirkimais (Reichheld, 2003). Galima teigti, kad tai ilgalaikis procesas, tiriantis tiek vartotojišką elgseną, tiek vartotojo emocinę būseną ir aplinką. Tuo tarpu G. Žigienè ir G. Maciūtè (2006) daro prielaidą, kad lojalumą lemia klientu pasitenkinimas. G. Bodet (2012) iškèlè hipotezę, kad patenkinti vartotojai yra labiau linkę būti ištikimais, ir kad nepatenkinti vartotojai mažiau tampa lojaliais. Pasak A. Ferrand ir kt. (2010) pasitenkinimas sporto centrų klientams yra teigiamai susijęs su jų noru rekomenduoti paslaugą ir dažniau lankytis sporto klube. Vartotojas gali būti patenkintas tiek produktu, tiek jo kokybe arba pačios organizacijos veikla (Bakanauskas, Pilelienè, 2008). J. Bivainis ir kt. (2011) teigia, kad pasitenkinimas gali būti suvokiamas kaip lojalumo priežastis. Visgi reikia pastebèti, kad nepatenkinti klientai ne visada renkasi konkurentus, o patenkinti kartais tai daro (Žigienè, Maciūtè, 2006). Taigi teikiama paslauga turi teikti tam tikrą pasitenkinimą, formuodama klientų lojalumą, kaip teigia M. Fraering ir M. S. Minor (2013), nuo pat pažinties pradžios per išorinius ir vidinius veiksnius, kurie bus aptarti toliau.

\section{Išoriniai veiksniai}

Klientų pasitenkinimas kuriamas, atrodo, nuo paprasčiausių dalykų - tokių kaip pirmasis apsilankymas (Bakanauskas, Pilelienė, 2008), „bendravimas su personalu“ (Komskienė ir kt., 2009). Būtent pirmaji ịspūdị apie organizaciją kuria jos darbuotojai, jų kompetentingumas, jie ne tik savo bendravimu, šypsenomis kuria centro ịvaizdị, bet ir darbo atlikimo kokybe pritraukia klientą ir kuria jo lojalumą (Komskienè ir kt., 2009). Taigi norint organizacijai išsiugdyti lojalų klientą, visų pirma reikalinga mokyti, skatinti ir formuoti lojalų, motyvuotą ir kūrybingą personalą. Todèl organizacijos tikslas yra sukurti tokią aplinką, atmosferą ir sąlygas, kad darbuotojai mėgautųsi savo darbu. Suformuota tinkama komanda turès ịtakos paslaugų teikimui, ir tai siejasi su organizacijos, kaip institucijos, identiteto dalimi ir yra lemiamas veiksnys, formuojantis lojalų klientą fitneso sektoriuje.

Organizacijos identitetas - tai sujungtas stiliaus, komunikacijos ir elgsenos per prekini ženklą suvokimas ir atspindys, dažnai klientų paprastai ịvardijamas ịvaizdžiu. Klientai ịvaizdị apie sporto klubą susidaro per fizinị akivaizdumą, t. y. jo nuomonę veikia įmonès pastatas, biuras, baldai, reklaminiai įmonès veiklos plakatai, jų spalvų gama ir pan. (Komskienè ir Švagždienė, 2013), pats bendravimo stilius, pavyzdžiui, interneto svetainëje ar socialiniuose tinkluose ar atitinkanti tikrovę organizacijos filosofija, personalo paslaugų teikimo kokybè. A. Ferrand ir kt. (2010) pabrèžè, kad kai paslaugas yra sunku įvertinti, sporto klubo įvaizdis ar prekès ženklas (Bakanauskas, Pilelienè, 2008; Durukan, Bozaci, 2011) yra pagrindinis veiksnys, kuris daro įtaką klientų pasitenkinimui paslauga. Taigi galima teigti, kad yra teigiamas ryšys tarp ịvaizdžio plačiąja prasme, organizacijos identiteto ir pasitenkinimo. Reikia atkreipti dèmesi, kad gražiausias interjeras ar reklaminis klipas neatstos pačios paslaugos, t. y. fitneso programos struktūros kokybès, kuri susijusi su pasitenkinimu ir daro ịtaką lojalumui, todèl teikiamos paslaugos, kaip sveikatingumo programos ir pasirinkimo galimybės, tampa reikšmingos lojalaus kliento formavimo dalimi.

Sveikatingumo programos. Jei sveikatingumo programos neduoda laukiamos naudos (pvz., negali pagerinti sveikatos, sumažinti streso, pagerinti nuotaikos), klientai galètų jas ịvertinti 
neigiamai, o tai mažina žmogaus norą sportuoti (Alexsandris et al., 2004). Kartais klientai negali pamatyti ar pajausti šių teigiamų pasekmių dèl sveikatingumo programų ilgalaikio pobūdžio, ir tai mažina galimybes sporto klubams išlaikyti klientą. Be to, neretai šios programos parengiamos ir siūlomos „kiekvienam“, o ne individualiai klientui pagal poreikius ir lūkesčius.

Pasirinkimas. Vartotojai yra išrankūs, nes pasirinkimo galimybių yra labai daug. Siekiant išlaikyti ir formuoti lojalų vartotoją sporto klubas turi įdèti dideles pastangas ị skirtingas sferas ir atkreipti dèmesi $\mathfrak{i}$ šiuos pagrindinius aspektus kuriant paslaugą: kokybės ir kainos santykị, personalo elgseną, teigiamų emocijų ir klubo ịvaizdžio kūrimą, instruktorių skaičių ir jų individualaus dèmesio klientui skyrimą, švarą, temperatūrą, patogumą bei modernius ịrenginius (Komskienè, Švagždienè, 2013), kad klientai liktų patenkinti ir atejjus pakartotinio pirkimo laikotarpiui rinktųsi tokią organizaciją.

Lemiamos reikšmės kuriant paslaugą, kuri patenkintų lūkesčius ir formuotų lojalų klientą, turi ir išoriniai veiksniai, susiję su tokiomis socialinėmis grupėmis kaip draugai, tèvai ir žiniasklaida (Tsioutsou, 2013).

Žiniasklaida ir žmonès. Šiuo metu vis didèja socialinès žiniasklaidos ịtaka vartotojų elgsenai: informacijos gavimas, bendravimas, taip pat teigiami ir neigiami atsiliepimai apie prekès ženklą ar produktą / paslaugą, ir tai veikia lojalumą (Laroche et al., 2012). Pirma, socialinė žiniasklaida leidžia įmonėms pasikalbėti su savo klientais, ir, antra, ji leidžia klientams kalbėtis vienam su kitu. Socialinè žiniasklaida taip pat leidžia vartotojams kalbėti su įmonėmis (Mangold, Faulds, 2009). Taip pat pastebèta, kad žmonès, kurie seka prekės ženklus, dažniau juos mato ir juos atpažista, labiau linkę pirkti ir rekomenduoti tuos ženklus produktus / paslaugas (Laroche et al., 2012). Taigi tarp žiniasklaidos ir lojalumo yra reikšmingas ryšys. Tradicinè rinkodaros išmintis jau seniai nusprendè, kad nepatenkintas klientas pasakoja dešimčiai žmonių. Bet tai yra pasenę. Naujame socialinès žiniasklaidos amžiuje klientas turi įrankius tai pasakyti $10 \mathrm{mln}$. vartotojų beveik per naktic (Mangold, Faulds, 2009). Vadinasi, tai tampa ypač svarbia priemone, kuri gali ir sukurti, ir sugriauti trapius lojalumo ryšius.

Kiekvienas žmogus turi skirtingą derinị savybių ir kiekvienas iš jų yra unikalus: suvokimas, mąstymas ir elgesys yra skirtingi (Durukan, Bozaci, 2011). Kiekvienas individas yra skirtingas ir turi ypatingų psichologinių, demografinių ir kitokių ypatumų (Zikienè, Brazinskaitè, 2012), todèl patiria skirtingus jausmus ir mintis, jie elgiasi skirtingai tomis pačiomis situacijomis, todèl lojalumą lemia atskiros tam individui būdingos savybès (Durukan, Bozaci, 2011). Žmogaus asmenybė yra vertinama kaip labiausiai svarbus veiksnys vertinant individualius ir organizacinius santykius (Durukan, Bozaci, 2011), todèl toliau apibūdinami vidiniai veiksniai.

\section{Vidiniai veiksniai}

Psichologiniai. Daroma prielaida, kad psichologinis vaidmuo yra ne mažiau svarbus nei tiesioginiai santykiai (Bodet, 2012). Būtent kai kurie vartotojai tampa psichologiškai tvirti ir renkasi tas pačias prekes ar tuos pačius paslaugų tiekejjus, nors yra ir neigiamų atsiliepimų apie juos, jie vis tiek lieka tvirtesni kaip klientai (Fraering, Minor, 2013). Tokie vartotojų vidaus psichologiniai veiksniai kaip grupès interesai, netiesioginiai motyvai, pasiekimai, jaudulys, savistabos skatinančio požiūrio būti ištikimu savo mėgstamos sporto organizacijos gerbejju apima ir pažintinius, ir 
emocinius elementus (Tsioutsou, 2013). Remiantis T. Durukan ir I. Bozaci (2011), šios psichologinès savybės: emocinis stabilumas, ekstraversija, atvirumas patirčiai, sutariamumas, sąmoningumas, pasireiškiančios asmenyse, formuoja juos būti ištikimais, savo pasirinktai sporto organizacijai. Šių penkių veiksnių modelis daugelyje skirtingų šalių ir kultūrų rodo, kad šie penki veiksniai yra svarbiausi asmenybès komponentai (Durukan, Bozaci, 2011). Kiti mokslininkai išskiria lyties, amžiaus, kainos, požiūrio ir rizikos aspektus, veikiančius lojalumą formuojančią aplinką.

Demografiniai. Amžius parodo, kad jaunesni vartotojai yra mažiau linkę prisirišti, jie labiau linkę laisvai ir neribotai rinktis vieną ar kitą organizaciją. Vyresni žmonès mažiau linkę ieškoti naujovių, dažniau pasilieka prie vieno pardavejjo ar paslaugos teikèjo (Zikienė, Brazinskaitè, 2012). Kaina parodo, kad žmogus, turintis mažiau pinigų, turi mažesni pasirinkimo ratą, todèl jis labiau linkęs pasilikti prie pigesnès ir vieną produktą teikiančios organizacijos. D. Komskienè ir B. Švagždienè (2013) pastebi, kad aukštaji išsilavinimą turintys žmonès daugiau kreipia dėmesio ị sveikatinimą, lengviau suvokia naudą, todèl pasitelkus tinkamus rèmimo komplekso komunikacijos kanalus, galima formuoti nuomonę apie klubą, jie lengviau pasiduoda įtikinimui, nes aiškiau supranta naudą. Išsilavinę klientai nuolat meta iššūkị pasitempti, t. y. tapti konkurencingesniais dèl to, kad išlaikytų juos klientų sąrašuose (Fraeringas, Minor, 2013). Socialinis statusas taip pat turi itakos klientų išlaikymui, nes neretai tam tikri fitneso klubai yra skirstomi pagal klientus. Ne veltui atsiranda „aukštuomenès“, „pramogų verslo žvaigždžių“, „verslininkų“, „banditų“ ar kitų ne prekinių sporto klubų ženklų. Socialinis statusas šiuo atveju tampa psichologiniu komfortu arba diskomfortu, jei klientas patenka ne i tinkamą aplinką, nes jị supantys klientai, personalas ir kiti veiksniai gali būti neadekvatūs priprastai sociokultūrinei patirčiai. Be to, gyvenamoji ar darbo vieta, taip pat gali būti svarbus veiksnys rinktis vieną ar kitą fitneso klubą, nes dažnai atsisakymo sportuoti priežastimi yra nurodomas laiko, o ne pinigu stygius. Jei klientui teks važiuoti per visą miestą piko metu, kad ir i pati geriausią klubą, greičiausiai jis rinksis artimiausią. Šiuo atveju, tai nebūtų galima ịvardyti kaip lojalumą antruoju atveju, tačiau pirmuoju, pagrịstai. Taigi vieni asmenys dèl savo individualių savybių ir yra labiau linkę tapti lojaliais, kiti - mažiau (Zikienè, Brazinskaitè, 2012). Reikia atkreipti dèmesị, kad individualios savybès čia koreliuoja su tam tikromis aplinkybėmis, netgi mada ar pačios asmenybės įvaizdžio formavimu.

Socialiniai. Būtina nuosekliai siekti santykių stiprinimo galimybių su klientais (Fraering, Minor, 2013). Organizacija turi pati investuoti i santykius su klientu, i kliento lojalumo kūrimą, grindžiamą potencialaus gyvavimo vertès padidèjimo prognoze (Žigienè, Maciūtè, 2006). Tokie lojalumą formuojantys veiksniai kaip santykių kokybė, ankstesnè patirtis, pasitikèjimas (Zikienė, Brazinskaite, 2012) įrodo tiek asmeninių, tiek socialinių veiksnių ryší. Tokie socialiniai ryšiai tarp klientų ir gamintojų ar paslaugų teikèjų gali būti vadinami draugiškais ryšiais (Fraering, Minor, 2013). Sporto paslaugų teikèjai turi sukurti tarpasmeninius santykius su savo klientais, tai ypač taikoma sveikatingumo klubams, kai tiek administracijos personalas ir fitneso specialistai tiesiogiai bendrauja su klientais (Alexsandris et al., 2004) kurdami „draugystę“, nes tokie vartotojai yra ištikimesni ir dažniau rekomenduoja sporto klubą draugams (Ferrand et al., 2010). Tiekèjo ir kliento santykių virsmas draugyste priklauso ir nuo žmonių individualių savybių. Taip atsitinka, kai 
atsidavimas prekès ženklui peržengia lojalumo ribas ir perauga ị draugiškumo santykius (Fraering, Minor, 2013).

\section{Lojalų klientą formuojančių veiksnių įtaka fitneso organizacijos aplinkai}

Taigi atsidavimas (lojalumas) priklauso nuo vidinių (žmogaus) ir išorinių (aplinkos) veiksnių, kur išoriniai kuriami, koreguojami ir integruojami į paslaugų kokybės vadybą, susijusią su vidiniais, tuo būdu generuodami pasitenkinimą, formuojantị lojalų klientą. Tačiau tai taip pat priklauso ir nuo kitų veiksnių. Remiantis mokslinių studijų analize, lojalų klientą formuojantys veiksniai pateikti paveiksle.

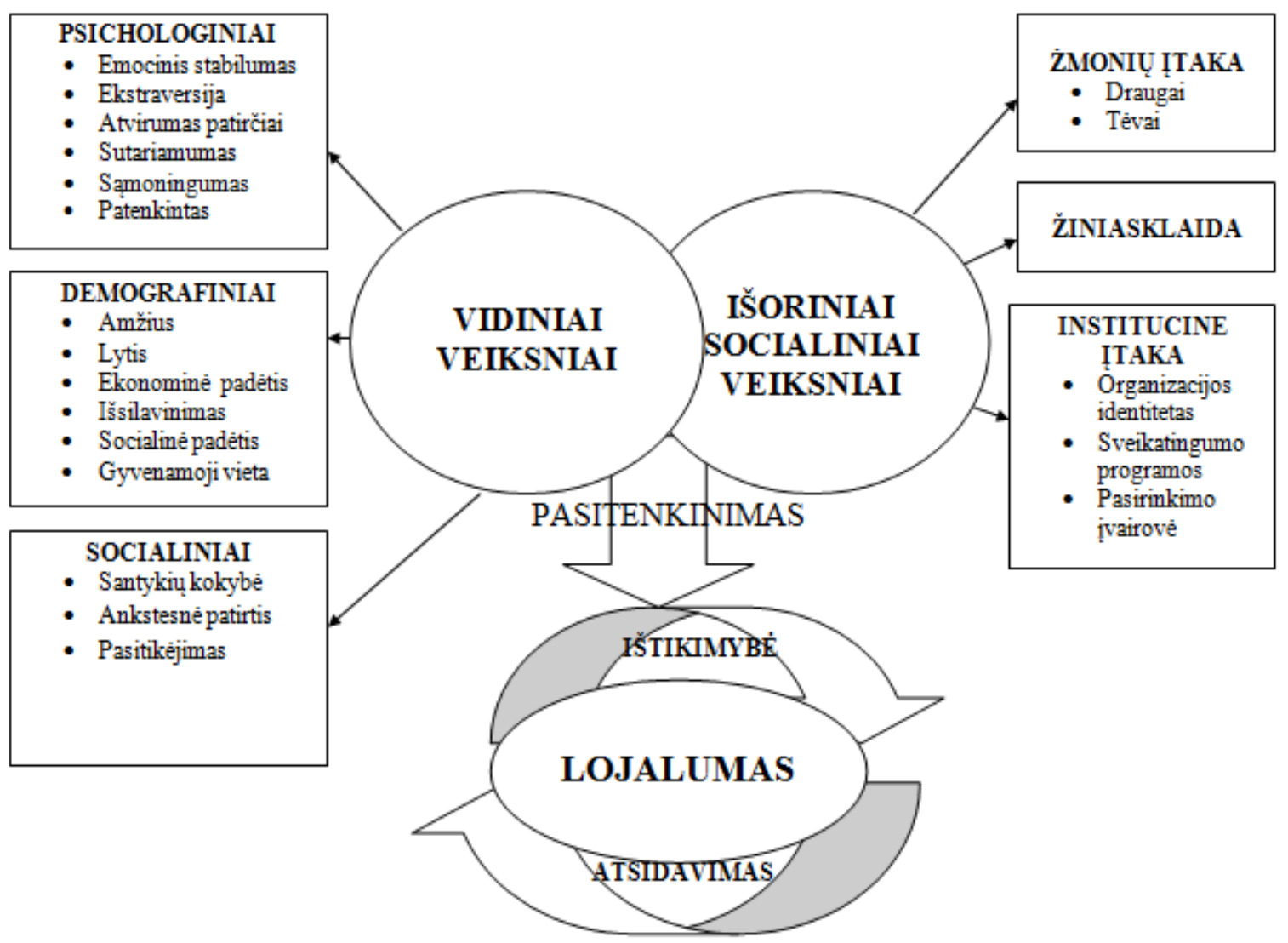

Pav. Lojalų klientą formuojantys veiksniai

K. Hawkins ir P. Vel (2013) pastebejjo, kad sukurti paslaugą tiekejjas turi per klientu „malonumą“ ir teikti jiems didesnę vertę. Svarbu nustatyti ne vartotojo pasitenkinimo lygi, o ar vertè, kurią pastarasis gavo, yra pakankama, kad išlaikytų ji lojalioje aplinkoje (Reichheld, 2006). Todèl M. Fraering ir M. S. Minor (2013) teigia, kad yra tiesioginis ryšys tarp pasitenkinimo, lojalumo, tvirtumo ir bendruomeniškumo jausmo. A. Bakanauskas ir L. Pilelienè (2008) teigè: nors pasitenkinimas ir yra būtinas vartotojų lojalumui garantuoti, jis negali būti tapatinamas su vartotojų lojalumu. F. F. Reichheld (2003) taip pat pastebi, kad vartotojų lojalumas yra daug daugiau nei pakartotiniai pirkimai - vartotojas gali pirkti pakartotinai iš inercijos, abejingumo ar pasitraukimo barjerų, o ne dèl lojalumo. Bet tai nereiškia, kad vartotojas nuolat pirks tą patị produktą ar paslaugą jei tas produktas / paslauga jam neduos naudos ir jis nebus patenkintas issigytu produktu / paslauga. Vartotojai šiandien kokybę vertina ne tik pagal tai, kas yra siūloma ir parduodama, bet ir kaip tai padeda patenkinti jų norus ir poreikius (Vanagienè, Ramanauskienè, 2007). Taigi organizacija 
turètų mokytis suprasti klientą (Hawkins, Vel, 2013), tai padètų kurti aplinką, formuojančią lojalų klientą. Anot T. Durkan ir I. Boazci (2011), vartotojų lojalumą formuojančią aplinką lemia ir organizacijos atmosfera, jos rezultatai, unikalumas ir pažinimas, t. y. vartotojams svarbu, kaip jie jaučiasi būdami tos organizacijos nariais, siekia kuo labiau pažinti sporto klubą ir jaustis patogiau, saugiau, taip pat nori, kad jų mègstamas sporto klubas stebintų unikalumu, naujais pasiūlymais. Vadinasi, reikia nepamiršti maloniai nustebinti klientą (t. y. daryti kažką, pvz. siurprizus, kad klientas džiaugtųsi), tokie poelgiai padeda sukurti palankią ženklo patirtí, būna paliestos kliento emocijos ir gali teigiamai paveikti jų polinkị kartoti pirkimus (elgsenos lojalumą), tačiau gali būti nepasirengę kurti požiūrio lojalumą (Hawkins, Vel, 2013).

Lojalūs vartotojai irgi turètų prisidèti prie organizacijos tobulèjimo, kad organizacija geriau tenkintų vartotojų lūkesčius. Lojalūs klientai ị įmonę žiūri su gera valia, visada rodo norą išreikšti nepasitenkinimą ir duoti laiko jai išspręsti šias problemas (Sin et al., 2006). Taip bendradarbiaudama organizacija su klientais gali pasiekti didelių laimejjimų, naudą gaus ne tik įmonè, bet ir klientai. Ilgalaikių santykių su paslaugos ar prekès tiekejju metu lojalūs vartotojai taip pat gauna ir socialinę naudą, kuri apima familiarumo, draugystès ir socialinès paramos jausmą (Glinskienè ir kt., 2010). Taigi priklausomai nuo esančių lojalių klientų fitneso klube sudaroma tam tikra aplinka naujai atejusiems ar ne taip , ¿sigyvenusiems“ klientams. Jei lojalūs klientai demonstruoja nepasitenkinimą naujai atėjusiais, nes bus mažiau vietos ar teks laukti įrenginio arba prisiims „šeimininkų“ ir „visažinių“ vaidmenį, tai kurs destrukcinę lojalų klientą formuojančią aplinką. Šiuo atveju ypatingą reikšmę turi personalo gebejjimas bendrauti su tokiais klientais, laiku tai pastebėti, laviruoti ir moderuoti situacijas organizacijos gerovès vardan per klientu pasitenkinimą.

Atlikus mokslinès literatūros analizę ir sisteminimą, lojalų klientą formuojančią aplinką fitneso sektoriuje galima apibrezžti kaip tarpasmeninès ir funkcinès vadybos rezultatą, plètojamą pasitelkiant: organizacijos gebejjimą užtikrinti, valdyti viešąą ir vidinę komunikaciją, taip pat mikroklimato per teigiamas emocijas kūrimą, atsižvelgiant $\mathfrak{i}$ klientams darančius ịtakos vidinius veiksnius ir koreliuojančias aplinkybes; nuoširdaus, lankstaus ir kompetentingo kolektyvo kūrimą, patogios vietos atranką, tinkamo laiko pasiūlą, švarą, sportinio inventoriaus komplektaciją, (Komskienè, Švagždienė, 2013; Ferrand et al., 2010), nuolatini tyrinejjimą ir mokymąsi, kokybiškų paslaugų teikimą, klientų ir klientų, klientų ir personalo „draugystės“ stiprinimą, siekiant individualaus, o ne „kiekvienam“ pasitenkinimo sveikatingumo programų teikimo kontekste.

\section{IŠVADOS}

1. Lojalumas yra trapus reiškinys ir pakankamai nepastovus. Visgi šis reiškinys dažnai teikia realią naudą organizacijai: pastovias pajamas, sumažèjusias marketingo išlaidas, rekomendacijas galimiems ir esamiems sporto vartotojams, naujų klientų pritraukimą, didesni konkurencingumą ir mažesnị jautrumą kainos svyravimams. Lojalus sporto klientas sporto organizacijoje formuojamas skiriant didelị dėmesị vartotojui, puoselèjant draugiškus santykius ir sukuriant malonią aplinką, sutelkiant pastangas suteikti 
kokybiškas paslaugas, siekiant klientų pasitenkinimo per sveikatingumo programas, pasirinkimą ir personalo „draugystę“.

2. Veiksniai, kurie formuoja lojalų klientą, daro ịtaką fitneso organizacijos vadybiniams sprendimams, susietiems su atitinkamos aplinkos plètra, kuomet kuriamas pasitikèjimas per klientų išklausymą ir tarpasmeninių ryšių kūrimą, efektyvų vidinio proceso judejjimą, paslaugu kūrimą pagal demografinius vidinius veiksnius ir sporto vartotojo individualizavimą teikiamų paslaugų ir „draugystės“ pagrindu per kliento patenkinimą. Fitneso organizacijos aplinka turi būti orientuota $\mathfrak{i}$ nuolatines individualias kliento studijas ir formuoti pasiūlymus, atsižvelgiant i tokius kliento vidinius psichologinius veiksnius kaip žmogaus asmeninès savybès, kurių išskiriamos šios: emocinis stabilumas, ekstraversija, atvirumas patirčiai, sutariamumas, sąmoningumas. Vidinių veiksnių interpretacijos ryšys su išoriniais socialiniais veiksniais (su žmonėmis, socialine žiniasklaida ir institucine įtaka) iš dalies generuoja komfortišką aplinką pasitenkinimui kurti, transformuodama ị lojalaus kliento formavimą.

\section{LITERATŪRA}

1. Alexsandris, K., Zahariadis, P., Tsorbatzoudis, C., Grouios, G. (2004). An empirical investigation of the relationship among service quality, customer satisfaction and psychological commitment in a health club context. European Sport Management Quarterly, 4(1), 36-52.

2. Bakanauskas, A., Pilelienè, L. (2008). Organizaciju vadyba: sisteminiai tyrimai.

3. Bivainis, J., Dauksevičiüté, I., Vilkaité, N. (2011). Ryšių rinkodara per vartotojų lojalumo prizmę. Verslas: teorija ir praktika, 12(4), 348-361.

4. Bodet, G. (2012). Loyalty in sport participation services: An examination of the mediating role of psychological commitment. Journal of Sport Management, 26(1), 30-42.

5. Cahill, D. L. (2007). Customer loyalty in third part logistics relationships. In W. A. Müller, M. Bihn (Eds.), Physica-Verlag: A Springer Company (Vol. 1, pp. 7-19). Heidelberg: Leipzig.

6. Donskis, L. (2005). Ar Lietuva patiria lojalumo krizę? Bernardinai. Prieiga internetu: http://www.bernardinai.lt/index.php?url=articles/28710 [žiūrèta 201302 21].

7. Durukan, T., Bozaci, I. (2011). The role of individual characteristics on customer loyalty. Journal of Business and Social Science, 23(2), 213-218.

8. Ferrand, A., Robinson, L., Florence, P. V. (2010). The intention-to-repurchase paradox: A case of the health and fitness industry. Journal of Sport Management, 24, 83-105.

9. Fraering, M., Minor, M. S. (2013). Beyond loyalty: Customer satisfaction, loyalty, and fortitude. Journal of Services Marketing, 27(4), 334-344.

10. Glinskienè, R., Kvedaraitė, N., Kvedaras, M. (2010). Vartotojų lojalumo stiprinimas - reikšmingiausia šiuolaikinių įmonių siekiamybè. Ekonomika ir vadyba: aktualijos ir perspektyvos, 4(20), 40-52.

11. Hawkins, K., Vel, P. (2013). Attitudinal loyalty, behavioural loyalty and social media: An introspection. Academic Journal, 13(2), 125-141. 
12. Komskienè, D., Švagždienè, B., Benetytė, M. (2009). Development of loyalty of employees in contemporary sports organization. Socialiniai tyrimai, 2(16), 32-34.

13. Komskienè, D., Švagždienė, B. (2013). Sporto klubų paslaugų dizaino reikšmè vartotojams (LSU studentu atliktų tyrimų pagrindu). Sportini darbinguma lemiantys veiksniai (VI): moksliniu straipsniu rinkinys (pp. 111-119). Kaunas: LSU.

14. Laroche, M., Habibi, M. R., Richard, M. O., Sankaranarayanan, R. (2012). The effects of social media based brand communities on brand community markers, value creation practices, brand trust and brand loyalty. Computers in Human Behavior, 28(5), 1755-1767.

15. Mangold W. G, Faulds, D. J. (2009). Social media: The new hybrid element of the promotion mix. Business Horizons 52, 357-365.

16. Papšienè, P., Vilkaitè, N. (2009). Vartotojų lojalumas kaip efektyvios žmogiškujų ištekliu vadybos rezultatas. Journal of Management, 14(2), 127-135.

17. Pilelienè, L. (2008). Pardavimu skatinimu pagristas vartotoju lojalumo formavimas: daktaro disertacija. Kaunas: Vytauto Didžiojo universitetas.

18. Reichheld, F. F. (2003). The One Number You Need to Grow. (Vol. 82, pp. 1-11). Harvard Business Review.

19. Reichheld, F. F. (2006). Esminis klausimas: Kaip užtikrinti gera pelna ir tikra augimą. Vilnius: Verslo žinios.

20. Sin, L. Y. M., Tse, A. C. B., Chan, H. (2006). The effects of relationship marketing orientation on business performance in the hotel industry. Journal of Hospitality \& Tourism Research, 30(4), 407-426.

21. Tsioutsou, R. (2013). Sport team loyalty: Integrating relationship marketing and a hierarchy of effects. Journal of Services Marketing, 27(6), 458-471.

22. Vanagienè, V., Ramanauskienè, J. (2007). Vartotojų lojalumo prekès ženklui įvertinimas. Vadybos mokslas ir studijos - kaimo verslu ir ju infrastruktūros plètrai, 11(4), 100-108.

23. Zikienè, K., Brazinskaitè, V. (2012). Asmeninių charakteristikų įtakos vartotojų lojalumo formavimuisi nustatymas. Organizaciju vadyba: sisteminiai tyrimai. doi: 10.7720/MOSR.1392-1142.2012.63.8.

24. Zikienè, K. (2010). Vartotoju lojalumas: formavimas ir valdymas. mokomoji knyga. Kaunas: Vytauto Didžiojo universitetas.

25. Žigienè, G., Maciutè, G. (2006). Lojalumo programos ịvertinimas finansiniu ir rinkodaros požiūriais. Tiltai, 1(34), 29-36. 


\title{
LOYALTY FORMING ENVIRONMENT IN FITNESS ORGANIZATION
}

\author{
Diana Komskienė, Ernesta Urbonavičiūtė \\ Lithuanian Sports University, Kaunas, Lietuva
}

\begin{abstract}
Research background. It has been estimated that today's fitness organizations urgently need to have and maintain loyal customers. An approach to have a loyal/faithful customer is very important for every organization. The organization should strive not only to attract, but also to retain the client. For client attraction and retention such personal human characteristics as emotional stability, extraversion, openness to experience, and awareness are mentioned as factors most affecting human loyalty. Of course, there are more important factors that shape a loyal customer: the interior, which consists of psychological, demographic and social factors as well as external stakeholders including fitness organization environment which comprises the people, the social media and institutional influence. Taking into account loyal customers forming factors a fitness organization should develop interpersonal relationships with their customers by creating "friendships" because that improves a fitness club environment where customers can directly interact with each other and with the staff, and ensure the quality of the relationship as well as build trust. Organizational aim is to develop loyal employees in their environment who are able to promote exceptional friendliness and sincerity, comfort and pleasant environment, commitment to organization and work relationships. In addition, the fitness organization must ensure the cleanness and quality of the inventory, the supply of fitness programs in accordance with customers' needs, age and education, not just for "everyone", as the most important customer satisfaction components of service which generate value, and in this way forming an inner image of the organization, and through the media and customer reviews - loyal environment that allows achieving positive results, growth and profit by increasing revenue and developing competitiveness.
\end{abstract}

Research aim was to establish conditions for a loyal customer forming environment in fitness organization.

Objectives: 1) Describe the concept of loyalty and expression; 2) Reveal loyal customers and influencing factors on the environment of fitness organizations.

Conclusions. Loyalty is a fragile phenomenon rather than erratic. However, this phenomenon often provides real benefits to the organization: fixed income, reduced marketing expenses, recommendations to potential and existing sports customers, attracting new customers, more competitive and less sensitive to price fluctuations. Formatting loyal sports customer a sports organization has a strong focus on friendly relations and fostering the creation of a pleasant environment, focusing its efforts to provide quality services and achieve customer satisfaction through wellness programs, selection and creation of client-personnel "friendship". Factors determining formation of loyal customers affects fitness organizations managerial decisions of the environment in the development of trust, created through customer listening and interpersonal relationships, in the development of an effective movement of the internal process, the creation of internal factors according to demographic criteria and individualization of services providing for sports customers through customer satisfaction on the "friendship" meaning basis. Fitness organization environment must be focused on the individual client's regular studies and development of proposals on the basis of the internal psychological factors, such as personal traits, which are distinguished as follows: emotional stability, extraversion, openness to experience, consciousness. Internal factors in connection with the interpretation of the social externalities: people, social media, and the influence of institutional identity 
generates relatively comfortable environment to create satisfaction, transforming to the formation of a loyal customer.

Keywords: Loyal customer, satisfaction, services, fitness organization.

\title{
ЛОЯЛЬНОСТЬ ФОРМИРУЮШАЯ СРЕДА В ФИТНЕС ОРГАНИЗАЦИИ
}

\author{
Diana Komskienè, Ernesta Urbonavičiūtè \\ Литовский университет спорта, Каунас, Литва
}

\section{РЕЗЮМЕ}

Считается, что сегодняшним фитнес организациям очень важно иметь и поддерживать лояльных клиентов. Организация должна стремиться не только привлечь, но и удержать клиента. Для привлечения клиентов и удержания через личные человеческие качества, такие как эмоциональная устойчивость, экстраверсия, открытость к информированности используются как факторы, влияющие на человеческую лояльность. Конечно, есть более важные факторы, которые формируют лояльных клиентов. Различают внутреннюю, которая состоит из психологических, демографических и социальных факторов, а также внешними заинтересованными сторонами, которые включают в себе экологическую организацию фитнес и состоит из людей, СМИ и институционального влияния. Фитнес организации, принимая во внимание лояльные клиенты формирующие факторы, следует разработать межличностные отношения со своими клиентами, создавая "дружбу", потому что это есть фитнес-клуб среда, где клиенты могут непосредственно взаимодействовать друг с другом и с сотрудниками с целью обеспечения качества отношений и укрепления доверия. Цель организации заключается в разработке лояльных сотрудников в их среде, которые были бы в состоянии создать исключительную доброжелательность и искренность, комфорт и приятную атмосферу, приверженность организации и трудовые отношения. Кроме того, фитнес-организация должна обеспечить чистоту и качество инвентаря, поставки фитнес-программ в соответствии с потребностями клиентов, возраста и образования, а не только для "каждого", в качестве наиболее важных компонентов удовлетворённости клиентов сервиса, создавать ценности, и таким образом образовать внутренний имидж организации через средства массовой информации и отзывы клиентов - лояльную среду, что позволяет добиться положительных результатов, расти в прибыле за счёт увеличения доходов и развивать конкурентоспособность.

Цель - создание лояльных клиентов формирующую среду в фитнес-организации. Цели: 1) описать концепцию лояльности и выражения; 2) выявление определяющих факторов на лояльных клиентов в среде фитнес организации.

Выводы: лояльность является хрупким явлением, а не хаотическим. Тем не менее, это явление часто даёт реальные преимущества для организации, как с фиксированным доходом, сокращением расходов, рекламы, новых клиентов, больше конкурентоспособности и менее чувствительности к колебаниям цен. Лояльность в фитнес-организации - детерминант с высоким акцентом на дружественных отношений и содействия созданию приятной обстановки. Формирование лояльного клиента в фитнес-организации концентрирует свои усилия по предоставлению качественных услуг, выполнение которых относит с окружающей среды в фитнес-организации. Постоянные клиенты «формирование фитнес организации" среде связана с факторами, стимулирующими кого-то, чтобы стать лояльным. В основном, имеющие такие как доверие, качество 
обслуживания, внимательность персонала к клиенту, удовлетворение и других. Фитнес среда организации должна быть направлена на регулярные исследования индивидуального клиента и разработку предложений на основе внутренних психологических факторов, таких как личные качества - эмоциональная устойчивость, экстраверсия, открытость опыту, сознания. Внутренние факторы в связи с интерпретацией социальных внешних: людей, социальных медиа, и влиянием институциональной идентичности порождает относительно комфортные условия для создания удовлетворение, переходя к формированию лояльного клиента.

Ключевые слова: лояльные клиенты, удовлетворённость, услуги, фитнес-организации. 